\title{
PENGGUNAAN MEDIA GAMBAR UNTUK MENINGKATKAN KEMAMPUAN MENGGOLONGKAN HEWAN BERDASARKAN JENIS MAKANANNYA
}

\author{
Lenayanti, Br. $\mathbf{P}$ \\ Guru SLB Negeri Banda Aceh, Indonesia \\ lenapulungan@gmail.com
}

\begin{abstract}
Abstrak
Artikel ini memaparkan tentang upaya meningkatkan kemampuan menggolongkan hewan berdasarkan jenis makanannya dengan menggunakan media gambar. di Sekolah Dasar Luar Biasa (SLB) Negeri Banda Aceh Kelas VI tunagrahita. Tunagrahita merupakan individu yang utuh, unik serta mengalami perkembangan, sesuai tahapan umurnya, namun mereka memiliki hambatan dalam kecerdasan. Di sekolah mereka mengalami kesulitan belajar yang beragam. Penelitian tindakan kelas ini menggunakan metode kualitatif, terdiri dari dua siklus. Penelitian ini merupakan penelitian kualitatif dengan subjek penelitian pada siswa kelas VII sebanyak 5 (lima) orang. Analisis data menggunakan teknik analisis deskriptif dengan membandingkan kondisi awal dengan hasil-hasil yang dicapai pada setiap siklus. Hasil penelitian menunjukkan bahwa penggunaan media gambar dapat meningkatkan kemampuan siswa menggolongkan hewan berdasarkan jenis makanannya. Pada akhir siklus II, jumlah siswa yang tuntas $80 \%$ (4 siswa), belum tuntas $20 \%$ (1 siswa) nilai rata- rata kelas menjadi 73 dibandingkan dengan kondisi awal yaitu 63 .
\end{abstract}

Kata Kunci: Kemampuan, Media Gambar, Tunagrahita Sedang, dan Penelitian Tindakan Kelas.

\section{Abstract}

This article describes the efforts to improve the ability to classify animals by type of food using image media. at the Banda Aceh State Extraordinary School (SLB) Class VI with mental retardation. Mentally retarded individuals are individuals who are intact, unique and undergo development, according to their age stages, but they have obstacles in intelligence. At school they experience various learning difficulties. This classroom action research uses qualitative methods, consisting of two cycles. This research is a qualitative research with research subjects in class VII students as many as 5 (five) people. Data analysis used descriptive analysis techniques by comparing the initial conditions with the results achieved in each cycle. The results showed that the use of image media could improve students' ability to classify animals based on their type of food. At the end of cycle II, the number of students who completed $80 \%$ (4 students), not yet completed $20 \%$ (1 student) the class average score was 73 compared to the initial condition, namely 63.

Keywords: Ability, Image Media, Moderate Impairment, and Classroom Action Research. 


\section{PENDAHULUAN}

Ilmu Pengetahuan Alam (IPA) merupakan mata pelajaran yang mempelajari diri sendiri dan alam sekitar, yang menekankan kepada pemberian pengalaman langsung, dan bertujuan untuk mengembangkan kemampuan, menjelajahi, memahami alam sekitar secara ilmiah. Dengan demikian pengetahuan IPA menjadi sangat penting untuk dipelajari bagi Anak Berkebutuhan Khusus (ABK). Anak Tunagrahita merupakan individu yang utuh dan unik mereka dalam kehidupan sehari-harinya sama dengan anak lainnya. Perkembangan anak tunagrahita meliputi segala perubahan yang terjadi pada anak, baik perubahan fisik, perkembangan kognisi, emosi, maupun perkembangan psikososial yang terjadi dalam diri anak, sesuai dengan tahapan umurnya, tetapi disertai dengan hambatan dalam kecerdasan, dan penyesuaian diri dengan lingkungan sekitarnya. Dalam proses pembelajaran anak tunagrahita mengalami hambatan belajar yang beragam, dalam hal ini dibutuhkan kemampuan guru agar hambatan belajar yang ditemui dapat diminimalisir. Martasuta mengatakan: "secara umum anak tunagrahita adalah anak yang mempunyai kekurangan atau keterbatasan dari segi mental intelektualnya, di bawah rata-rata normal, (IQ $<70$ ), sehingga mengalami kesulitan dalam tugas-tugas akademik, komunikasi, maupun sosial. Anak tunagrahita memiliki klasifikasi berbeda". 1

Adapun pembahasan dalam penelitian ini adalah anak tunagrahita sedang (menurut

1 Martasuta, D,U. Modul Pembelajaran Anak Dengan Hambatan Kecerdasan. (Jakarta: Departemen Pendidikan Khusus, Fakultas Ilmu Pendidikan, Universitas Pendidikan Indonesia, 2015). h. 25 tingkat IQ moderate: IQ 40-45). Selanjutnya Rochyadi mengemukakan: "dalam proses pembelajaran pada anak tunagrahita memang terasa unik dan komplek, keunikan dan kekomplekan itu terjadi karena apa yang sedang dipelajari anak itu dengan prasarat yang belum dimilikinya kerap kali berjalan bersamaan". ${ }^{2}$ Perhatian anak tunagrahita dalam belajar tidak dapat bertahan lama mudah berpindah ke obyek lain yang terkadang sama sekali tidak menarik atau tidak bermakna, sehingga mengganggu aktifitas belajarnya, bahkan anak sendiri tidak menyadari apa yang dilakukannya. Rendahnya perhatian anak dalam belajar akan menghambat daya ingat. Dengan demikian diperlukan kemampuan guru untuk meningkatkan daya ingat anak. Menyadari pentingnya meningkatkan hasil belajar dengan mengacu kepada hasil pra pembelajaran yang rendah pada materi menggolongkan hewan berdasarkan jenis makanannnya pada anak tunagrahita sedang kelas VI di SDLB Negeri Banda Aceh, menjadi alasan bagi peneliti untuk memperbaiki atau meningkatkan hasil belajar anak tunagrahita dengan berbagai cara. Menurut Purwanto: "hasil belajar adalah perubahan perilaku peserta didik akibat belajar. Perubahan perilaku disebabkan karena dia mencapai penguasaan atas sejumlah bahan yang diberikan dalam proses belajar mengajar, dapat berupa perubahan dalam aspek kognitif, afektif dan psikomotorik." ${ }^{3}$ Adapun yang menjadi pilihan atau cara untuk meningkatkan

2 Rochyadi, dan Dudy. Modul Media Pembelajaran Anak Berkebutuhan Khusus: Mata Kuliah Media Pembelajaran dan TIK Bidang Studi Dalam Pendidikan Khusus, (Bandung: Universitas Pendidikan Indonesia, 2015). h. 4.

3 Purwanto, Evaluasi Hasil Belajar. (Jogjakarta: Pustaka Pelajar, 2011), h. 46. 
hasil belajar, peneliti mencoba menggunakan media pembelajaran dengan menggunakan gambar. Penggunaaan media gambar dalam kelas sangat efektif dalam penyajiannya, gambar-gambar dapat terlihat oleh seluruh siswa dengan menggunakan berbagai tampilan, bisa ditempel, digantung, atau diproyeksikan, sehingga ruangan menjadi menarik, memotivasi, meningkatkan minat, perhatian, dan menambah pengetahuan siswa. Susilana (2008: 2) mengatakan bahwa: "dikaitkan dengan pembelajaran media dimaknai sebagai alat komunikasi yang digunakan dalam proses pembelajaran untuk membawainformasi berupa materi ajar dari pengajar kepada peserta didik sehingga peserta didik menjadi lebih tertarik untuk mengikuti kegiatan pembelajaran". Hal senada juga dikatakan Rochyadi "media pembelajaran dalam pendidikan anak pada dasarnya merupakan alat bantu dari aksi guru ketika melakukan intervensi." 4

Berdasarkan beberapa pendapat, di atas dapat disimpulkan pengertian media pembelajaran ialah segala bahan, alat, metode ataupun teknik yang digunakan untuk menyampaikan informasi dari sumber (guru) ke penerima informasi (siswa) selama proses pembelajaran sehingga dicapai proses pembelajaran yang lebih bermutu. Media pembelajaran dengan menggunakan gambar hewan, memungkinkan untuk diterapkan pada SDLB Negeri Banda Aceh dan diperkirakan dapat meningkatkan kemampuan daya serap sehingga berdampak terhadap prestasi siswa atau hasil belajar siswa. Hasil dari penelitian dengan menggunakan media gambar hewan

4 Susilana, R dan Riyana, C. Media Pembelajaran.Hakikat Pengembangan Pemanfaatan dan Penilaian. (Bandung: Wacana Prima, 2008), h. 2. ini dapat memberikan salah satu solusi dalam pembelajaran pada materi menggolongkan hewan berdasarkan jenis makanananya bagi anak tunagrahita sedang mata pelajaran IPA.

\section{LANDASAN TEORI}

\section{Pengertian Tunagrahita}

Dalam Peraturan Pemerintah Republik Indonesia Nomor 72 Tahun 1991 disebutkan bahwa: "tunagrahita berasal dari kata tuna yang artinya luka, rusak atau ketiadaan, grahita berasal dari kata panggraito yaitu akal budi. ${ }^{5}$ Sehingga pengertian tunagrahita sebagai luka atau tiadanya akal budi. Sedangkan menurut American Assocition on Mental Deficiency (AAMD) sebagaimana dikutip oleh Martasuta bahwa "ketunagrahitaan mengacu pada fungsi intelektualyang secarajelas berada dibawahratarata/normal disertai dengan kekurangan dalam tingkah laku penyesuaian dan terjadi dalam periode perkembangan." Anak tunagrahita mengalami keterlambatan dalam segala bidang, dan itu sifatnya permanen, rentang memori mereka pendek terutama yang berhubungan dengan akademik, kurang dapat berpikir abstrak dan pelik. Untuk anak-anak tunagrahita tertentu dapat belajar akademik yang sifatnya aplikatif. Akibat dampak ketunagrahitaan berbeda-beda, tetapi ada kesamaan masalah yang dirasakan bersama, ditinjau dari kontek pendidikan.

Martasuta mengatakan bahwa: Dampak dari ketunagrahitaan akan mengakibatkan permasalahan diantaranya: a) Kesulitan dalam kehidupan sehari-hari: berkaitan dengan

5 Depdiknas, Peraturan Pemerintah Republik Indonesia Nomor 72 Tahun 1991, (Jakarta: Balitbangdiknas, 2002), h. 2-4.

6 Martasuta, D,U. Modul Pembelajaran Anak Dengan Hambatan Kecerdasan. (Jakarta: Departemen Pendidikan Khusus, Fakultas Ilmu Pendidikan, Universitas Pendidikan Indonesia, 2015). h. 25 
kesehatan dan merawat diri; b) kesulitan belajar: karena keterbatasan berpikir, mengakibatkan kesulitan belajar terutama dalam bidang pengajaran akademik, sedangkan non akademik tidakbanyakmengalamimasalah;c)penyesuaian diri: ada kecenderungan diisolir masyarakat; d) gangguan kepribadian dan emosi: kurang. Memiliki kemampuan berpikir, keseimbangan pribadinya kurang konstan; e) pemanpatan waktu luang:, harus ada imbangan kegiatan dalam waktu luangnya; f) penyaluran tempat kerja: perlu dipikirkan secara matang dan ideal serta dapat diwujudkan dengan penanganan yang serius, g) masalah seksualitas: mengalami perkembangan, mengerti hubungannya dengan lingkungan, perlu mendapat pendidikan seks dan perlu mendengar informasi./mendapat informasi dari kedua orang tuanya. ${ }^{7}$ Dengan demikian, maka dapat dikatakan bahwa dampak ketunagrahitaa mengakibatkan berbagai permasalahan baik dari kehidupan keseharian sampai kehidupan bersosial dan bermasyarakat serta permasalahan belajarnya.

\section{Hasil Belajar Siswa}

Anak tunagrahita memiliki dua kriteria keterbatasan, yakni rendahnya fungsi kecerdasan/intelegensi dan keterampilan adaptif. Kedua aspek keterbatasan kemampuan tunagrahita tersebut menyebabkan terhambatnya perkembangan dan terbatasnya perkembangan kemampuan. Intelegensi merupakan fungsi yang kompleks yang dapat diartikan sebagai kemampuan untuk mempelajari informasi dan keterampilan-keterampilan menyesuaikan diri

7 Martasuta, D,U. Modul Pembelajaran Anak Dengan Hambatan Kecerdasan. (Jakarta: Departemen Pendidikan Khusus, Fakultas Ilmu Pendidikan, Universitas Pendidikan Indonesia, 2015). h. 55. dengan masalah dan situasi kehidupan baru, belajar dari pengalaman masa lalu, berfikir abstrak, kreatif, dapat menilai secara kritis, menghindari kesalahan, mengatasi kesulitankesulitan dan kemampuan untuk merencanakan masa depan. Anak tunagrahita memiliki kekurangan dalam semua hal tersebut. Kapasitas belajar anak tuna grahita terutama yang bersifat abstrak seperti belajar berhitung, menulis, dan membaca juga terbatas, kemampuan belajarnya cenderung tanpa pengertian atau cenderung belajar dengan membeo. ${ }^{8}$

Hambatan dalam proses kognitif tersebut membuat anak tunagrahita kesulitan dalam hal: menyadari situasi, benda, orang disekitarnya, tidak mampu memahami keberadaan dirinya. Hal tersebut disebabkan oleh faktor bahasa yang menjadi hambatan; sulit memecahkan masalah, tidak mampu membuat rencana bagi dirinya, sulit untuk memilih alternatif pilihan yang berbeda; Mereka sulit sekali untuk menuliskan simbol-angka, memiliki ksulitan dalam bidang membaca, menulis dan berhitung; Kemampuan belajar anak tunagrahita terbatas; Mereka mengalami kesulitan yang berarti dalam pengetahuan yang bersifat konsep dan dalam menempatkan dirinya dengan keadaan situasi lingkungannya. Fleksibilitas mental yang kurang pada anak tunagrahita mengakibatkan kesulitan dalam pengorganisasian bahan yang akan dipelajari. Oleh karena itu, sulit bagi anak tunagrahita untuk menangkap informasi yang kompleks. $^{9}$

8 Lena Yanti Br. Pulungan, Niswanto, Yusrizal, Pengembangan Kompetensi Profesional Guru Program Khusus Pada SDLB Negeri Banda Aceh, dalam Jurnal Administrasi Pendidikan Vol. 5, No. 3 (2017), h. 7-8.

9 Lena Yanti, Pengembangan Kompetensi Profesional Guru Program Khusus (Konsep dan Teori), (Banda Aceh: Bandar Publishing, 2017), h. 18. 
Layanan pendidikan sebagai upaya untuk mengoptimalkan penyerapan informasi pada anak tunagrahita dapat dilakukan dengan memberikan pengalaman langsung dan konkret dalam pembelajaran. Pemberian pembelajaran langsung dan konkret merupakan salah satu upaya meningkatkan hasil belajar siswa. Hasil belajar merupakan hal yang berhubungan dengan kegiatan belajar, karena kegiatan belajar merupakan proses, sedangkan hasil belajar adalah sebagian hasil yang dicapai seseorang setelah mengalami proses belajar dengan terlebih dahulu mengadakan evaluasi dari proses belajar yang dilakukan. Menurut Purwanto "hasil belajar adalah perubahan perilaku peserta didik akibat belajar. Perubahan perilaku disebabkan karena dia mencapai penguasaan atas sejumlah bahan yang diberikan dalam proses belajar mengajar, dapat berupa perubahan dalam aspek kognitif, afektif dan psikomotorik." 10

\section{Media Pembelajaran}

Susilana mengatakan bahwa: "dikaitkan dengan pembelajaran media dimaknai sebagai alat komunikasi yang digunakan dalam proses pembelajaran untuk membawa informasi berupa materi ajar dari pengajar kepada peserta didik sehingga peserta didik menjadi lebih tertarik untuk mengikuti kegiatan pembelajaran". Dengan demikian yang perlu diingat adalah bahwa peranan media tidak akan terlihat apabila penggunaannya tidak sejalan dengan isi dan tujuan pembelajaran yang telah dirumuskan. ${ }^{11}$ Sedangkan Sadiman, dkk

10 Purwanto, Evaluasi Hasil Belajar. (Jogjakarta: Pustaka Pelajar, 2011), h. 46.

11 Susilana, R dan Riyana, C. Media Pembelajaran.Hakikat Pengembangan Pemanfaatan dan Penilaian. (Bandung: Wacana Prima, 2008), h. 2. mendefinisikan media sebagai segala sesuatu yang dapat digunakan untuk menyalurkan pikiran, perasaan, dan minat serta perhatian siswa sedemikian rupa sehingga proses belajar terjadi." ${ }^{12}$ Hal senada juga dikatakan Rochyadi "media pembelajaran dalam pendidikan anak pada dasarnya merupakan alat bantu dari aksi guru ketika melakukan intervensi. ${ }^{13}$

\section{Pembelajaran Anak Berkebutuhan Khusus (ABK)}

$$
\text { Media pembelajaran bagi anak }
$$

berkebutuhan khusus dalam perkembangannya sering digunakan dengan istilah media adaptif, istilah ini berkembang karena perubahan paradigma yang terjadi dalam pendidikan khusus. Dalam persepektif pendidikan khusus sekurang-kurangnya ada tiga peran media pembelajaran yaitu: (1) media sebagai alat bantu dalam proses pembelajaran (alat peraga), (2) media sebagai alat untuk mengungkap masalah dan hambatan belajar (asessmen), (3) dan media sebagai alat bantu dalam pengembangan aspek psikologi dasar (teraputik). ${ }^{14}$

Efektifitas media pembelajaran bagi ABK tidak diukur dari kecanggihan medianya, tetapi lebih pada fungsi media tersebut. Adapun manfaat media pembelajaran bagi ABK: 1) Penggunana media pembelajaran bagi ABK bukan hanya untuk membantu dalam pemahaman kognitif saja tetapi membantu dalam hambatan fisik, motorik dan perilaku, 2)

12 N. Sudirman, et al. eds, Ilmu Pendidikan. (Bandung : PT Remaja Rosda Karya, 2015,) h. 3.

13 Rochyadi, E. Modul Pendidikan Anak Berkebutuhan Khusus, (Bandung: Departemen Pendidikan Khusus, Fakultas Ilmu Pendidikan, Universitas Pendidikan Indonesia, 2015), h. 3.

14 Lena Yanti, Pengembangan Kompetensi Profesional Guru Program Khusus (Konsep dan Teori), (Banda Aceh: Bandar Publishing, 2017), h. 19-20. 
Membantu guru dalam melakukan intervensi, sehingga kegiatan pembelajaran lebih efektif dan efisien, 3) Penyampaian materi pembelajaran dapat diseragamkan dengan bantuan media pembelajaran penafsiran yang berbeda dapat dihindari dan dapat mengurangi terjadinya kesenjangan informasi. Zubaidah, dkk menyatakan bahwa: "manfaat media dalam pendidikan adalah dapat membangkitkan keinginan dan minat baru, meningkatkan motivasi dan rangsangan kegiatan belajar, dan bahkan berpengaruh secara psikologis kepada siswa." " Sedangkan menurut Rochyadi "kegunaan dari media pembelajaran bagi ABK adalah sebagai alat bantu belajar (bahasa dan matematika)." ${ }^{16}$

\section{METODOLOGI PENELITIAN}

Metodepenelitianyang digunakanadalah Classroom Action Research atau penelitian tindakan kelas. Metode Penelitian Tindakan Kelas (PTK) digunakan untuk menawarkan cara dan prosedur baru untuk memperbaiki dan meningkatkan profesionalisme guru dalam proses belajar mengajar di kelas dengan melihat berbagai indikator keberhasilan proses dan hasil pembelajaran yang terjadi pada siswa. Tindakan yang digunakan dalam penelitian ini adalah pembelajaran menggunakan media gambar hewan, sedangkan akibat dari

15 Zubaidah, Rahmad Syah Putra, Fithriani Gade, Lightening The Learning Climate Sebagai Upaya Mewujudkan Pembelajaran yang Menyenangkan Bagi Mahasiswa Program Studi Ilmu Perpustakaan UIN Ar-Raniry pada Mata Kuliah Bahasa Inggris dengan Menggunakan Aplikasi Zoom, dalam Indonesian Journal of Library and Information Science Vol. 1, No. 1 (2020), h. 7 .

16 Rochyadi, E. Modul Pendidikan Anak Berkebutuhan Khusus, (Bandung: Departemen Pendidikan Khusus, Fakultas Ilmu Pendidikan, Universitas Pendidikan Indonesia, 2015), h. 5. tindakan berupa kemampuan menggolongkan hewan berdasarkan jenis makanannya yaitu menggolongkan hewan pemakan tumbuhan (herbivora), pemakan daging (karnivora), dan pemakan segala (omnivora) pada anak tunagrahita sedang. Perubahan dapat dilihat dari perbedaan hasil sebelum diberikan tindakan siklus I dan setelah diberikan tindakan siklus II. Desain ini memberikan pre test terlebih dahulu sebelum diberikan perlakuan dan diberikan post test setelah diberi perlakuan dengan instrument tes yang sama. Hasil pre tes dan post test dibandingkan untuk mengetahui pengaruh dari perlakuan yang telah diberikan. Subjek penelitian adalah siswa tunagrahita sedang Kelas VI yang berjumlah 5 siswa. Instrument tes yang digunakan berupa tes tertulis yang berisikan pertanyaanpertanyaan untuk mengukur kemampuan meenggolongkan berdasarkanjenis makananya yaitu menggolongkan hewan pemakan tumbuhan (herbivora), pemakan daging (karnivora), dan pemakan segala (omnivora).

\section{HASIL DAN PEMBAHASAN \\ Hasil Penelitian}

Data hasil penelitian berupa nilai tes pra siklus dan nilai tes siklus I, dan II yang mengukur kemampuan menggolongkan hewan berdasarkan jenis makanannya yaitu menggolongkan hewan pemakan tumbuhan (herbivora), pemakan daging (karnivora), dan pemakan segala (omnivora) pada peserta didik tunagrahita sedang sebelum dan setelah diberikan perlakuan pembelajaran dengan menggunakan media gambar hewan sebagai berikut; 


\begin{tabular}{|c|c|c|c|c|}
\hline \multirow{2}{*}{ No } & \multirow{2}{*}{ Hasil Tes } & \multicolumn{3}{|c|}{ Jumlah Siswa Yang Berhasil } \\
\cline { 3 - 5 } & & Pra Siklus & Siklus I & Siklus II \\
\hline 1 & 100 & - & - & 1 \\
\hline 2 & 80 & - & - & 1 \\
\hline 3 & 70 & - & 2 & 2 \\
\hline 4 & 68 & 1 & 2 & 1 \\
\hline 5 & 60 & & 1 & - \\
\hline 6 & 55 & - & 1 & - \\
\hline 7 & 50 & 2 & 1 & - \\
\hline 8 & 45 & & 1 & - \\
\hline 9 & 40 & 2 & - & - \\
\hline
\end{tabular}

Tabel 1. Perbandingan Hasil Nilai Tes Pra Siklus, Siklus I dan II

Peningkatan hasil tes kemampuan belajar siswa dapat ditunjukkan melalui gambar grafik di bawah ini:

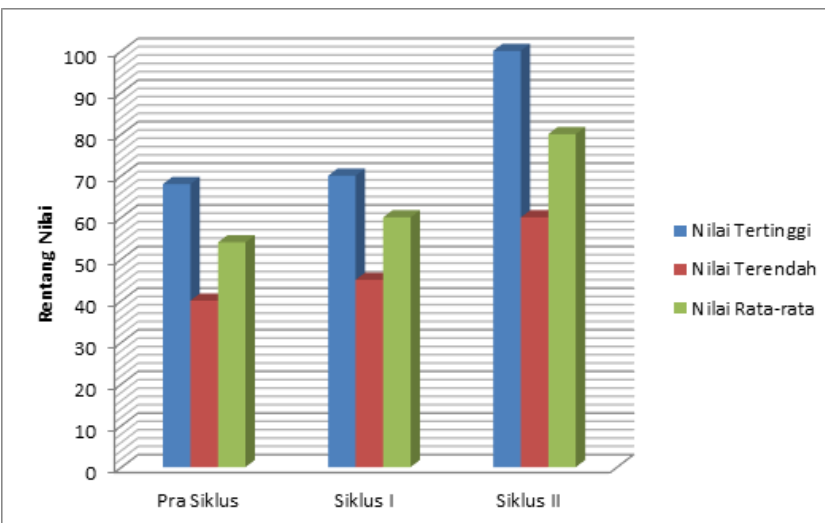

Gambar 1. Perbandingan Hasil Tes Pra Siklus, Siklus I, dan Siklus II

Dari Grafik 1 di atas menunjukan bahwa hasil tes pra siklus, dan hasil tes siklus I, dan II pada peserta didik tunagrahita sedang sebelum dan sesudah diberikan perlakuan yaitu pembelajaran dengan menggunakan media gambar hewan pada grafik terlihat nilai tes pra siklus terendah 40 dan tertinggi 48, sedangkan nilai siklus I tertinggi 70 , terendah 45 , demikian juga untuk nilai siklus II, tertinggi 100, dan terendah 68.

\section{Pembahasan}

Hasil penelitian menunjukkan adanya perbedaan yaitu nilai tes siklus II lebih tinggi dari pada nilai siklus I dan pra siklus, hal ini menunjukan adanya pengaruh pembelajaran dengan menggunakan media gambar hewan. Pemberian perlakuan dengan pembelajaran media gambarhewan pada pelaksanaannya terdiri dari dua siklus. Media gambar hewan yang digunakan pada siklus I dan II terdapat perubahan yaitu dengan menggunakan sumber belajar yang lebih beragam, baik buku-buku pendukung, poster dan pemberian tugas. Pemberian Materi dan gambar hewan, serta pelaksanaan pre test dan post test disesuaikan dengan kondisi anak 
tunagrahita sedang dengan mengggunakan bahasa, dan gambar yang sederhana sehingga mudah dimengerti oleh anak tunagrahita. Proses pembelajaran dengan menggunakan media gambar hewan dilaksanakan dengan tiga tahapan utama, yaitu pertama, menggolongkan hewan pemakan tumbuhan (herbivora), dilanjutkan dengan menggolongkan hewan pemakan daging (karnivora), dan diakhiri dengan hewan pemakan segala (omnivore). Pembelajaran dengan menggunakan media gambar hewan ini berguna untk membiasakan peserta didik tunagrahita sedang terlatih untuk mengingat dan memahami, apa yang disampaikan dan dipelajari.

Pelaksanaan siklus pada tahap pertama guru menyampaikan tujuan pembelajaran, mempersiapkan gambargambar tujuannya agar peserta didik dapat mempersiapkan diri menerima pembelajaran, sehingga mudah memahami. Tahap kedua guru hanya sedikit memberikan penjelasan selanjutnya peserta didik melaksanakan tugas secara kelompok, dengan panduan lembar kerja siswa. Pada tahap ketiga peserta didik melakukan diskusi secara sederhana, dan melaporkan hasil kelompoknya, pada tahap ini peran guru hanya sedikit, tetapi guru memancing peserta didik terlebih dahulu untuk mengetahui sejauh mana kemampuan peserta didik dan kesulitan yang dihadapi. Pada akhir pembelajaran guru memberikan apresiasi kepada seluruh siswa, kemudian guru memperjelas dan melengkapi hal-hal yang pada saat diskusi kurang dipahamai peserta didik.

Penggunaan media gambar hewan yang digunakan dalam proses pembelajaran menggolongkan hewan berdasarka jenis makanannya dapat membantu meningkatkan kemampuan pada anak tunagrahita sedang dikarenakan karateristik anak tunagrahita adalah pembelajaran konkrit, sehingga memudahkan anak tunagrahita dalam mengikuti pembelajaran di kelas. Penggunaan pembelajaran dengan menggunakan media gambar hewan ini mempunyai kelebihan yaitu langkah-langkah yang terdapat dalam pembelajaran tersusun secara sistematis bertujuan untuk membantu peserta didik tunagrahita sedang dalam mempertahankan ingatan dalam jangka waktu lama sehingga dapat membantu dan membimbing peserta didik untuk bisa memahami materi dalam setiap langkah-langkahnya.

\section{KESIMPULAN}

Mengacupadapenelitiandanpembahasan ditemukan bahwa penggunaan media gambar dalam pembelajaran IPA khususnya pada kompetensi dasar, menggolongkan hewan berdasarkan jenis makanannya bagi siswa kelas VI tunagrahita sedang SDLB Negeri Banda Aceh tahun pelajaran 2018/2019 dapat meningkatkan kemampuan siswa. Hal ini dapat dilihat dari kemampuan awal siswa saat pra siklus ketercapaian ketuntasan belajar sebesar $20 \%$ ( 1 siswa) yang belum mencapai ketuntasan $80 \%$ (4 siswa), pada akhir siklus I ketuntasan belajar yang dicapai sebesar $40 \%$ (2 siswa) dan yang belum mencapai ketuntasan belajar sebesar $60 \%$ (3 siswa), sedangkan pada akhir siklus II, ketuntasan belajar yang dicapai sebesar $80 \%$ (4 siswa) dan yang belum mencapai ketuntasan belajar sebesar $20 \%$ ( 1 siswa). Dengan nilai rata- rata kelas pra siklus 54, siklus I 58 dan nilai rata- rata kelas siklus II 80. Adapun 
hasil observasi pada proses pembelajaran menunjukkan perubahan sikap siswa menjadi lebih aktif, dan gembira, serta memberikan respon senang dengan meningkatnya nilai ratarata kelas

\section{DAFTAR PUSTAKA}

Depdiknas, Peraturan Pemerintah Republik Indonesia Nomor 72 Tahun 1991, Jakarta: Balitbangdiknas, 2002.

Lena Yanti Br. Pulungan, Niswanto, Yusrizal, "Pengembangan Kompetensi Profesional Guru Program Khusus Pada SDLB Negeri Banda Aceh", Jurnal Administrasi Pendidikan Vol. 5, No. 3, Agustus (2017), 7-8.

Lena Yanti, Pengembangan Kompetensi Profesional Guru Program Khusus (Konsep dan Teori), Banda Aceh: Bandar Publishing, 2017.

Martasuta, D,U. Modul Pembelajaran Anak Dengan Hambatan Kecerdasan. Jakarta: Departemen Pendidikan Khusus, Fakultas Ilmu Pendidikan, Universitas Pendidikan Indonesia, 2015.

N. Sudirman, et al. eds, Ilmu Pendidikan. Bandung: PT Remaja Rosda Karya, 2015.
Purwanto, Evaluasi Hasil Belajar. Jogjakarta: Pustaka Pelajar, 2011.

Rochyadi,danDudy.ModulMediaPembelajaran Anak Berkebutuhan Khusus: Mata Kuliah Media Pembelajaran dan TIK Bidang Studi Dalam Pendidikan Khusus, Bandung: Universitas Pendidikan Indonesia, 2015.

Rochyadi, E. Modul Pendidikan Anak Berkebutuhan Khusus. Bandung: Departemen Pendidikan Khusus, Fakultas Ilmu Pendidikan, Universitas Pendidikan Indonesia, 2015.

Susilana, R dan Riyana, C. Media Pembelajaran. Hakikat Pengembangan Pemanfaatan dan Penilaian. Bandung: Wacana Prima, 2008.

Zubaidah, Rahmad Syah Putra, Fithriani Gade, "Lightening The Learning Climate Sebagai Upaya Mewujudkan Pembelajaran yang Menyenangkan Bagi Mahasiswa Program Studi Ilmu Perpustakaan UIN Ar-Raniry pada Mata Kuliah Bahasa Inggris dengan Menggunakan Aplikasi Zoom," Indonesian Journal of Library and Information Science Vol. 1, No. 1 June (2020), 7. 